\title{
REFLECTIONS
}

\section{Almost Invariably}

When they first met, his certainty was one of his most attractive features. It was what she most lacked. What she had was a piece of parchment declaring her a nurse, youth, and a surfeit of empathy and good intentions. She was overwhelmed at times by the world she found herself in: a seemingly endless line of tubes, medications, and blinking call lights - reams of linen bedclothes covered in the various effluents of humanity. Everywhere there were wrecked lives looking to her for some manner of comfort. It was more than she had bargained for. At each shift's end, when her pulse slackened and the flush receded from her face, she felt the soft discomfort of finding herself in a place to which she did not fully belong. Rarely during the day did she feel confident, either in her decisions or her actions. Nothing that was asked of her, save empathy, came naturally or comfortably. Against her discomfort he stood out in sharp relief.

Were she to answer honestly, even from the distance of 15 years, she would have admitted that it was his appearance that first appealed to her. She first glimpsed him standing at the clerk's desk at the end of the hall. She had felt the chaos of her inexperience in every harried step of the entire eight weeks of her nascent career and that day was no exception. She was damp and crumpled and consumed with remembering that one thing on the endless list of things that were her tasks for that day that she was certain she had overlooked. She had just counted out the pills, twelve in all, for the elderly woman in 6112 whose name she could not remember, when she turned and, catching her heel on the carpet, scattered herself and the tablets across the hall. Embarrassed, as much by the tears she fought back as by the awkward posture she found herself in, she paused and allowed herself imperceptibly to sag when she caught a glimpse of him. She missed his gaze, but was certain he had seen her.

He looked so pressed. Sharp creases everywhere. Pant legs - cuffed, crisp. Shirt sleeves, starched and stiff. He scrawled something quickly in the chart he held and then snapped it shut. He held it across to the nurse at the desk and with great economy spoke an order which she heard but could no longer recall. She realized in a way that she had not before that it was just such orders that were the source of the blur of her days.

It was his habit to make decisions. It was his job as well. Quick decisions. Decisions that often saved lives. Decisions that could end lives as well. He never seemed to belabor them. It was only a matter of weighing the facts. Risk versus benefit. It was as if he had his own scale onto which the opposing points of each decision were carefully stacked. His task was first to examine each piece and then to carefully place it on the scale. The decision was simply a matter of to which side the scale fell. He trusted the process completely and never reconsidered a decision. That he was rarely if ever wrong was a fact that he could truthfully and liberally quote. In the event of a bad outcome he could never blame his decision. If called to re-examine his decision, he could walk through the process, explain why the scale tilted as it did and be certain that if he had to make exactly the same call again, he would do the same thing for the same reason.

She came, with time, to resent it - the unquestioning precision of his decisions and the superfluous role she played in the process. She felt like no more than a weighted piece of data to place on the scale - standardized and non-negotiable. Whether it was "Alan" (the name of his father and their first son), the type of fescue in the lawn, the color of the drapes, or the time they should spend visiting respective families for the holidays, he was as consistently unwavering and certain in his decisions as he would be in deciding to remove an appendix.

If she questioned him she received a short review of the data and the relative weight of each factor. She felt her neck tighten every time they went through the process. He had phrases he used to introduce his pronouncements. "Almost invariably," was his favorite. She knew what he meant by it. He meant he was not certain of the outcome of his actions but he was certain of the actions he would take. To her, no matter how small the choice, there was always some moral weight to a decision - some little piece of right and wrong. She felt it, yet without the clarity he always had when examining options. She once told a girlfriend that not once in all their years together had she ever felt he "got it." Logic couldn't account for it and he therefore had no access to the notion.

She looked across the bed at him and sniffed back her own tears. She thought about the words and what they meant. "Brain dead." "Tissue donation." "Withdrawal of care."

She looked again at her young son, buried in the bed, while the neurologist's question hung in the air.

Her husband's brow creased and still he said nothing.

Her voice trembled. "Honey?" 